\section{Pathway to innovation illuminated at 2015 MRS Fall Meeting}

\author{
www.mrs.org/fall2015
}

\begin{abstract}
A dvances in materials underpin many social advances, and materials scientists are key to enabling the transition of materials development from laboratory to market. Today, an increased pace of discovery is needed to meet the rising challenges in both established and new areas. But the process of bringing a product to market and building a sustainable enterprise is complex. Innovators need to understand how to build a business plan, find effective partners, secure funding, and understand their country's legal systems and resources, in addition to technical issues.*

An enthusiastic audience of scientists and engineers recently convened for the 9th Technology Innovation Forum (TIF) to
\end{abstract}

hear case studies of successful startups and advice on managing these challenges. This half-day event held during the 2015 MRS Fall Meeting brought together entrepreneurs from the United States and Europe to share their experiences. Organized by Meiken Falke (Bruker Nano GmbH Berlin), Eva Campo (Bangor University), and Wolfgang Jaeger (Universität Kiel), the forum focused on the theme "Entrepreneurship and Innovation in the International Year of Light—Approaches in Europe and America."

The UN General Assembly proclaimed 2015 as the International Year of Light and Light-Based Technologies to draw attention to how light-based technologies promote sustainable
Innovation ConneXions www.mrs.org/innovation-connexions

MRS Innovation ConneXions is a multifaceted program comprised of live interactions and online information to help materials entrepreneurs bring their technologies to market. Innovation ConneXions includes the Technology Innovation Forum (TIF), Innovation in Materials Science (iMatSci), and Resources and Opportunities.

Since its inception at the 2010 MRS Spring Meeting, TIF has hosted presentations and discussions on topics such as materials commercialization of energy solutions, challenges of bringing materials technologies to market, funding processes, market philosophies, business models, and connecting with investors to inform future entrepreneurs of what they need to know for success in bringing their technology to market.

iMatSci, launched at the 2014 MRS Fall Meeting, takes the process one step further by providing a platform where materials entrepreneurs can present their product prototypes directly to industry leaders and investors.

iMatSci is a great platform to connect advanced materials innovators and entrepreneurs with relevant angel, venture capital, and strategic investors. As Pangaea Ventures exclusively focuses on advanced materials, judging the participants is an effective way to network with both promising startups and other materials-focused investors.

-Matthew Cohen, Associate, Pangaea Ventures Ltd.

A growing web-based site on trends and contacts, Resources and Opportunities is a source that innovators will return to for advice, potential partner connections, and news. The site includes links to such things as the Chemical Angel Network and the MRS Bulletin Special Issue on "Materials \& Engineering: Propelling Innovation." (See also the MRS OnDemand video recording of the MRS Bulletin author discussion at www.prolibraries.com $/ \mathrm{mrs} /$ ?select= session\&session $I \mathrm{D}=6229$.)

An excellent issue! [This special MRS Bulletin] will turn heads and provoke lively conversation...

- George W. Crabtree, Director, Joint Center for Energy Storage Research development and provide solutions to global challenges in energy, education, agriculture, and health. "Many materials scientists are interested in how to use light from many angles," explained Falke. "And product harvesting or light production is also intertwined with this. So we chose the International Year of Light as our guideline for the 2015 fall session on entrepreneurship."

Falke became aware of the ongoing TIF series during an earlier MRS Spring Meeting. "I was hooked and volunteered to help," she explained. With her own work in the area of detector design and Campo's work involving electron/ion microscopy and synchrotron spectroscopy to draw upon, the two focused on bringing together key innovators in technologies that use light as a source of energy or as a means of materials characterization. They expanded the topic to also include innovators who use other analysis techniques in materials science, life sciences, and medicine.

The forum featured 12 speakers from the United Kingdom, Germany, Spain, Sweden and the United States, enabling comparison of experiences in their own startups for light diodes, solar cells, and instrumentation for analysis, pressure sensing, specimen preparation, and nanotechnology or in fostering national funding programs and education (see the TIF program on next page). Keynote speaker Sir Colin Humphreys (University of Cambridge) described how his work in producing gallium nitride LEDs on large-area silicon substrates would fill an environmental and economic need. He discussed his experience initially working with industry, his decision to start his own company, the start up of a second company, and the importance of intellectual property protection and his decision to sell his successful companies to a UK business despite having offers in several other countries. The experience brought added benefits to his research group. "I

*See also "From academic discovery to industrial applications: Innovation and success in materials science and engineering" (Phillip Ball, MRS Bulletin, December 2015) and MRS OnDemand ${ }^{\circledR}$ video of the Fall Meeting author session on the MRS Bulletin December issue "Materials \& Engineering: Propelling Innovation." www.prolibraries.com/mrs/?select= session\&sessionlD=6229. 
have been surprised by the enthusiasm of all the research students and postdocs in the $\mathrm{GaN}$ team to not only do excellent research, but also to think about whether that research could be useful to society and could be exploited commercially," he explained. "The GaN group now sees this as an added bonus to their research and are actively aware of exploitation opportunities."

Funding of new startups is critical and differs between the United States and Europe. Eric Stach (Hummingbird Scientific) described the Small Business Innovation Research (SBIR) and Small Business Technology Transfer (STTR) programs as significant sources of funding in the United States. SBIR is a highly competitive program that encourages small US businesses to engage in federal research and R\&D that has the potential for commercialization. The STTR program is designed to encourage joint venture opportunities by requiring small businesses to formally collaborate with a research institution. "By including qualified small businesses in the nation's R\&D arena, high-tech innovation is stimulated, and the US gains entrepreneurial spirit as it meets its specific R\&D needs," he said. "These programs are a great way to turn your ideas into products without diluting your equity."

"It was remarkable that the commercialization paths were so different among the speakers," Campo remarked. Lucille Giannuzzi (L.A. Giannuzzi \& Associates LLC) agreed that the individuals' abilities to leverage their technical skills played an important role in their success and illustrated this in her presentation. "Technical sales and marketing an idea or product are intuitive to those who 'see the forest through the trees," she said. "This tends to come naturally to scientists and engineers because we are trained to analyze and critique things." And since technical sales are usually to technical people, the entrepreneur's facts-based ideas and proposals are trustworthy. In addition, she counseled the audience to protect their ideas with patents and keep some information proprietary.
Although scientists and engineers have a firm foundation for moving their ideas to commercialization, they also need to seek out expertise in areas beyond their knowledge. A recurring piece of advice from the speakers was to employ an experienced CEO for a startup. "A friend told me that I might be a reasonable scientist, but I really would not be good at leading a company," said Humphreys. "Fortunately, I took his advice and appointed a good CEO to lead both of our companies." Stach emphasized the importance of a strong CEO, especially for entrepreneurs who intend to maintain their academic appointments.

Looking forward, the group was optimistic about the climate for innovation. Funding differences between the United States and Europe may not be as dissimilar in the future as Europe begins to look more to private investors in a manner more common in the United States. The group also saw opportunity for universities to strengthen their expertise to support the commercialization of science and IP protection.

While funding is critical to successful commercialization, the speakers cautioned, entrepreneurs will weather the obstacles and thrive when the idea or vision is driving the project rather than the money. Belief in how the technology will better our lives will sustain the entrepreneur and team through the difficult times.

Commercialization may take years, so a strong incentive is critical. And innovators are encouraged to remember Humphreys's most important advice: "Never, never give up."

Gail Oare
2015 MRS Fall Meeting TIF Program

KEYNOTE: Bridging the Gap Between Science and a Real ProductA Case Study on LED Lighting (Sir Colin Humphreys, University of Cambridge)

Heliatek-A Joint Spin-Out from Two Universities on Its Way from Technology Leadership to Mass Production of Organic Solar Foils (Martin Pfeiffer, Heliatek GmbH)

Tools for NanotechnologyGrowing a Company that Provides Hardware for Scientific Discovery (Eric A. Stach, Hummingbird Scientific)

Deciding between the Start-Up vs. Licensing Pathway (Dawnielle Farrar-Gaines, Johns Hopkins University)

An Introduction to the Swedish Innovation Systems (Axel Steuwer, Invest in Skåne)

The Entrepreneur's Entrée

(lan Ferguson, Missouri University of Science and Technology)

Building a Nanotechnology Company from Scratch: Funding in Advanced Materials Market-The Graphenea Case (Jesus de la Fuente, Graphenea Inc.)

How to Start Up a High-Tech Company Out of a Research Center and Establish It Successfully on the Market (Jörg Wiesmann, Incoatec GmbH)

From Materials Science and Engineering to Running a Company (Lucille $A$. Giannuzzi, L.A. Giannuzzi \& Associates LLC)

Innovation and Growth-A View from the Organic Side (Warren Oliver and John Swindeman, Nanomechanics, Inc.)

Germany's New Materials Research Program "From Materials to Innovation"Challenges and Opportunities (Herbert Zeisel, Federal Ministry of Education and Research [BMBF])

Creating Wealth with Your Brain-Why Engineers Are Fabulously Positioned to Become Successful Entrepreneurs (Jesko A. von Windheim, Duke University)

\section{Plan to Attend-2016 MRS Spring Meeting TIF}

The 10th Technology Innovation Forum will be held during the 2016 MRS Spring Meeting on March 29 (Phoenix, Arizona) on "Unlocking Innovation at National Labs: How Do Government Research Laboratories Most Effectively Help Bring About Technology Commercialization?," organized by Vladimir Matias (iBeam Materials, Inc.) and Orlando Auciello (The University of Texas at Dallas). The keynote speaker is Steven Chu, the William R. Kenan, Jr., Professor of Physics and Professor of Molecular and Cellular Physiology, Stanford University and former US Secretary of Energy. 